Jurnal Health Sains: p-ISSN: 2723-4339 e-ISSN: 2548-1398

Vol. 3, No. 1, Januari 2022

\title{
PENGARUH KONFLIK PERAN DAN JENJANG KARIR TERHADAP PRODUKTIVITAS KARYAWAN DENGAN KOMITMEN ORGANISASIONAL SEBAGAI VARIABEL MEDIASI DI RS LEONA KUPANG
}

\author{
Mitzi, Muhammad Fachruddin Arrozi, Rina Anindita \\ Universitas Esa Unggul, Jakarta, Indonesia \\ Email: mitzijoe1991@yahoo.com, zarrozi@esaunggul.ac.id,rina.anindita@esaunggul.ac.id
}

\begin{tabular}{ll}
\hline INFO ARTIKEL & ABSTRAK \\
\hline Diterima & Produktivitas Karyawan adalah sebuah isu yang sangat penting dalam \\
5 Januari 2022 & dunia kerja terutama di industri Rumah Sakit. Hal ini dikarenakan dalam \\
Direvisi & sebuah rumah sakit, salah satu hal yang dijual adalah jasa. Jasa ini pasti \\
15 Januari 2022 & erat kaitannya dengan sumber daya manusia dan komitmen dia \\
Disetujui & produktivitasnya dalam bekerja. Banyak faktor yang dapat \\
25 Januari 2022 & mempengaruhinya, baik faktor internal dan eksternal. Penelitian ini \\
\hline Kata Kunci: & bertujuan untuk melihat Pengaruh Konflik Peran dan Jenjang Karir \\
konflik peran; & terhadap Produktivitas Karyawan dengan komitmen organisasional \\
jenjang karir; & sebagai variabel mediasi. Teknik analisa yang dipergunakan path \\
produktivitas & analysis. Populasi sampel penelitian ini adalah seluruh staf di RS Leona \\
karyawan; & Kupang berjumlah 158 orang. Teknik pengambilan sampel \\
komitmen & menggunakan Kuota Sampling dengan desain penelitian cross-sectional. \\
organisasional; & Pengukuran dalam penelitian ini menggunakan kuesioner yang disebar \\
analisa jalur & kepada 158 responden dan kuesioner yang kembali sebanyak 100\%. \\
& Hasil penelitian menunjukkan bahwa konflik peran, jenjang karir dan \\
& komitmen organisasional memiliki pengaruh signifikan terhadap \\
& produktivitas karyawan. Namun temuan pada penelitian ini bahwa \\
& konflik peran berpengaruh negatif terhadap produktivitas karyawan \\
& sedangkan jenjang karir dan komitmen organisasional juga berpengaruh \\
& positif terhadap produktivitas karyawan. Implikasi penelitian untuk \\
& mendorong manajemen mengembangkan strategi untuk meningkatkan \\
& produktivitas karyawan.
\end{tabular}

Keywords:

role conflict; career

development;

employee

productivity;

\begin{abstract}
Employee productivity is an important issue, especially in the hospital industry due to its nature as a service industry. Service Industry is related to human resources and their commitment to productivity at work. Productivity may get impact from many factors, both internal and external. This study aims to see the effect of role conflict and career development on employee productivity with organizational commitment as intervening variable. This study use path analysis with all staff in Leona Kupang Hospital consist of 158 person as the sample population. The sampling technique of research was a quota sampling study with a cross-sectional research design. Total sampling is used as the method to measure the survey. Measurements in this study using a questionnaire distributed to 158 respondents with 100\% respond. The results showed that role conflict, career path and organizational commitment had a significant effect on employee productivity. The research finding is that role conflict has a negative effect on employee productivity. While
\end{abstract}


Pengaruh Konflik Peran dan Jenjang Karir terhadap Produktivitas Karyawan dengan Komitmen Organisasional sebagai Variabel Mediasi di RS Leona Kupang

\begin{tabular}{ll}
\hline organizational & $\begin{array}{l}\text { career path and organizational commitment has a positive effect on } \\
\text { commitment; path } \\
\text { analysis }\end{array}$ \\
management to develop strategies to increase employee productivity.
\end{tabular}

\section{Pendahuluan}

Menurut WHO (World Health

Organization), rumah sakit adalah bagian integral dari suatu organisasi sosial dan kesehatan dengan fungsi menyediakan pelayanan paripurna (komprehensif), penyembuhan penyakit (kuratif) dan pencegahan penyakit (preventif) kepada masyarakat. Sedangkan berdasarkan undangundang No. 44 Tahun 2009 tentang rumah sakit, yang dimaksudkan dengan rumah sakit adalah institusi pelayanan kesehatan yang menyelenggarakan pelayanan kesehatan perorangan secara paripurna yang menyediakan pelayanan rawat inap, rawat jalan, dan gawat darurat. Fenomena yang terjadi di RS Leona Kupang adalah karyawan khususnya perawat dalam hal ini memiliki tingkat produktivitas yang rendah, karena pekerjaan dan kehidupan pribadinya bercampur. Sering terjadi adalah perawat yang memiliki anak, akan menjemput anaknya di sekolah saat jam dinas di rumah sakit. Hal ini membuat rumah sakit tidak memiliki sumber daya manusia yang berkualitas. Sehingga, nantinya akan berujung pula pada income rumah sakit.

Berdasarkan uraian diatas penelitian ini bertujuan untuk melihat produktivitas karyawan di RS Leona Kupang dalam meningkatkan kinerja organisasi baik dari sisi keuangan maupun non keuangan, komitmen organisasional juga demi kemajuan bersama suatu organisasi tersebut. Serta adanya keingintahuan akan pengaruh dari hal-hal diluar hubungan interpersonal dalam menentukan terbentuknya komitmen organisasional daripada suatu anggota organisasi dan untuk mencari cara untuk meningkatkan efisiensi dan kemampuan suatu organisasi melalui komitmen organisasional dari para karyawannya. \begin{tabular}{lllr}
\multicolumn{2}{r}{ Produktivitas } & Karyawan menurut \\
(Indarjanti & $\&$ & Bodroastuti, & 2012), \\
produktivitas & kerja & adalah ukuran dari
\end{tabular} kuantitas dan kualitas dari pekerja yang telah dikerjakan dengan mempertimbangkan biaya sumber daya yang digunakan untuk mengerjakan pekerjaan tersebut. Produktivitas karyawan juga dipengaruhi oleh komitmen organisasional.

Menurut (Robbins et al., 2009) mendefinisikan komitmen organisasional adalah sebagai suatu keadaan dimana seorang karyawan memihak organisasi tertentu serta tujuan-tujuan karyawan tersebut dan keinginan untuk mempertahankan keanggotaan dalam organisasi tersebut.

Sedangkan jenjang karir menurut (Glueck et al., 1997), jenjang karir adalah peningkatan pribadi yang dapat dilakukan seseorang untuk mencapai suatu rencana karir yang telah direncanakan.

Dalam rumah sakit, banyak terjadi konflik peran, konflik peran sendiri memiliki definisi suatu kondisi yang simultan dari dua atau lebih bentuk tekanan pada tempat kerja, dimana pemenuhan dari satu peran membuat pemenuhan terhadap peran lainnya lebih sulit (Carnicer \& Gasca, 2004).

\section{Metode Penelitian}

Penelitian ini menggunakan metode penelitian cross-sectional dengan memilih sejumlah responden sebagai sampel dan mengajukan daftar pertanyaan (kuesioner). Jenis penelitian ini adalah kausalitas dengan pendekatan kuantitatif, dimana penelitian yang dilakukan dengan mengambil beberapa sampel dari suatu populasi dan menggunakan kuisioner sebagai alat pengumpul data. Tipe Penelitian menggunakan pengujian hipotesis dengan kausalitas atau sebab akibat. Populasi dari penelitian ini adalah seluruh 
karyawan di Rumah Sakit Leona Kupang yang berjumlah 260 orang. Sampel yang diambil pada penelitian ini berjumlah 158

\section{Hasil dan Pembahasan}

\section{A. Hasil Penelitian}

Teknik analisis data menggunakan analisis jalur/path analysis. Penelitian ini terdiri dari 4 variabel yaitu variabel konflik peran, jenjang karir, komitmen organisasional dan produktivitas karyawan dengan pernyataan setiap indikator pada kuesioner. Variabel konflik peran terdiri dari 3 indikator dengan 10 pernyataan pada kuesioner. Variabel jenjang karir terdiri dari 7 indikator dengan 19 orang dengan Teknik quota sampling yang biasa digunakan pada populasi yang mempunyai susunan berbeda beda.

pernyataan dalam kuesioner, dan variabel komitmen organisasional dengan 3 indikator terdiri dari 9 pernyataan pada kuisioner. Variabel produktivitas karyawan dengan 6 indikator terdiri dari 25 pernyataan pada kuisioner. Dari total 63 pernyataan yang ada di kuisioner, masing-masing indikator yang mempunyai lebih dari 1 pernyataan dibuat average terlebih dahulu. 158 jawaban responden diolah dengan menggunakan Path analysis-AMOS.

\section{Tabel 1}

Distribusi Karakteristik Responden

\begin{tabular}{lcc}
\hline \multicolumn{1}{c}{ Jenis Kelamin } & Frekuensi & Persentase(\%) \\
\hline Laki-laki & 61 & $38.61 \%$ \\
Perempuan & 97 & $61.39 \%$ \\
Jumlah & 158 & $100 \%$ \\
\hline Unit Kerja & Frekuensi & Persentase (\%) \\
Pendaftaran dan Admin & 7 & $4.43 \%$ \\
Rawat jalan & 13 & $8.23 \%$ \\
Farmasi & 11 & $6.96 \%$ \\
Radiologi & 3 & $1.90 \%$ \\
Laboratorium & 5 & $3.16 \%$ \\
IGD & 5 & $3.16 \%$ \\
Gizi & 7 & $4.43 \%$ \\
Unit Kerja & Frekuensi & Persentase $(\%)$ \\
Kasir dan Billing & 6 & $3.80 \%$ \\
Rawat Inap & 52 & $32.91 \%$ \\
Fisioterapi & 8 & $5.06 \%$ \\
Kamar bedah & 4 & $2.53 \%$ \\
Office & 25 & $15.82 \%$ \\
Lain-lain & 12 & $7.59 \%$ \\
Jumlah & 158 & $100 \%$ \\
& & \\
\hline Pendidikan Terakhir & Frekuensi & Persentase (\%) \\
\hline SD & 0 & $0 \%$ \\
SMP & 2 & $1.27 \%$ \\
SMA / SMK & 17 & $10.76 \%$ \\
D3 & 86 & $54.43 \%$ \\
D4 & 12 & $7.59 \%$ \\
Strata 1 & 41 & $25.95 \%$ \\
Jumlah & 158 & $100 \%$ \\
\hline \multicolumn{1}{c}{ 17-25 tahun } & & \\
& Frekuensi & Persentase (\%) \\
& 27 & $17.09 \%$ \\
\hline & &
\end{tabular}


Pengaruh Konflik Peran dan Jenjang Karir terhadap Produktivitas Karyawan dengan Komitmen Organisasional sebagai Variabel Mediasi di RS Leona Kupang

\begin{tabular}{ccc}
\hline 26-35 tahun & 71 & $44.94 \%$ \\
$36-45$ tahun & 38 & $24.05 \%$ \\
$46-55$ tahun & 18 & $11.39 \%$ \\
$>55$ tahun & 4 & $2.53 \%$ \\
Jumlah & 158 & $100 \%$ \\
& & \\
\hline Pekerjaan & Frekuensi & Persentase(\%) \\
\hline PNS & 12 & $13,33 \%$ \\
Non PNS/Kontrak & 78 & $86,67 \%$ \\
Jumlah & 90 & $100 \%$ \\
\hline
\end{tabular}

\section{a. Uji Normalitas}

Uji normalitas bertujuan untuk menguji apakah dalam sebuah model analisis jalur, variabel dependen, variabel independen atau keduanya mempunyai distribusi normal atau tidak normal. Dalam penelitian ini, data dikatakan normal jika nilai cr dari kurtosis pada baris terakhir lebih besar dari \pm 2.58 . Pada tabel dapat dilihat nilai cr pada kurtosis baris terakhir adalah 2,116 (data nomal). Hasil ini didukung dengan hasil uji normalitas secara univariate yang dilihat pada C.R Skewness yang memiliki rentang anka $-1,940-0,042$ yang seluruhnya masih dibawah $\pm 2,58$. Dengan demikian secara multivariat maupun univariate, data telah terdistribusi normal.

Tabel 2

Data Uji Normalitas

\begin{tabular}{lllllll}
\hline Variable & Min & Max & Skew & c.r & kurtosis & c.r \\
\hline Jenjang karir & 2.000 & 3.476 & -.308 & -1.580 & -.412 & -1.058 \\
\hline Konflik Peran & 1.800 & 3.800 & -.378 & -1.940 & -.598 & -1.534 \\
\hline $\begin{array}{l}\text { Komitmen } \\
\text { Organisasional }\end{array}$ & 2.000 & 3.778 & -.038 & -.197 & -.499 & -1.280 \\
\hline Produktivitas & 2.033 & 3.333 & .008 & .042 & .130 & .334 \\
\hline
\end{tabular}

\section{b. Uji Outlier}

Pada penelitian ini tidak ada satu oberservasi pun yang memiliki p-value $<0,001$ atau tidak terjadi outlier. Hal ini didukung dengan nilai Mahalanobis d-squared tertinggi adalah sebesar
17,468 masih lebih kecil dibandingkan nilai X2 tabel $(\mathrm{df}=4 ; 0.001)$ yaitu sebesar 18,467 . Hal ini menunjukkan bahwa data yang didapat berdistribusi normal.

Tabel 3

Uji Outlier

\begin{tabular}{cccc}
\hline Observation Number & Mahalanobis d-squared & $\mathbf{P}^{\mathbf{1}}$ & $\mathbf{P}^{\mathbf{2}}$ \\
\hline 119 & 17.468 & .002 & .220 \\
\hline 131 & 16.190 & .003 & .072 \\
\hline 137 & 15.016 & .005 & .038 \\
\hline 103 & 11.420 & .022 & .467 \\
\hline 58 & 10.592 & .032 & .560 \\
\hline 99 & 10.521 & .033 & .408 \\
\hline 49 & 10.269 & .036 & .346 \\
\hline 125 & 9.686 & .046 & .443 \\
\hline
\end{tabular}




\begin{tabular}{llll}
\hline 27 & 9.682 & .046 & .307 \\
\hline 68 & 9.606 & .048 & .222 \\
\hline
\end{tabular}

\section{c. Uji Multikolinearitas}

Uji ini dilakukan dengan melihat determinan matrikx kovarians. Dalam penelitian ini didapatkan nilai determinan matriks kovarian hasilnya 0.262 (hasil positif dan lebih besar dari 0.000 ) artinya tidak ada multikolinearitas.

\section{d. Uji Simultan}

Pada penelitian ini dilakukan analisis hipotesis dan faktor yang bersamaan dengan menggunakan AMOS-path analysis. Pada uji measurement model didapat hasil Chisquare sebesar 1,554 (nilainya kecil sehingga uji simultan diterima), degrees of freedom sebesar 1 dan probability level $0,212>0,05$ hal ini menandakan bahwa hipotesa pertama (H1) diterima.

\section{e. Uji Koefisien Determinan (R2)}

Analisis pengaruh determinasi dalam analisis AMOS-path analysis digunakan untuk mengetahui besar kontribusi variabel eksogen terhadap variabel endogen.

Tabel 4

Squared Multiple Correlations

\begin{tabular}{cc}
\hline & Estimate \\
\hline Komitmen Organisasional & 0.142 \\
\hline Produktivitas Karyawan & 0.357 \\
\hline
\end{tabular}

Berdasarkan tabel, diperoleh nilai estimate variabel komitmen organisasional sebesar $14,2 \%$ dan estimate variabel produktivitas karyawan sebesar 35,7\%. Dalam penelitian ini variabel komitmen organisasional dipengaruhi oleh konflik peran dan jenjang karir. Variabel produktivitas karyawan dipengaruhi oleh konflik peran, jenjang karir dan komitmen organisasional. Dari hasil analisis determinasi tersebut maka disimpulkan bahwa besar pengaruh konflik peran, jenjang karir dan komitmen organisasional terhadap produktivitas karyawan adalah sebesar
$35,7 \%$, sedangkan sisanya adalah sebesar $64,3 \%$ dipengaruhi oleh faktor lain diluar penelitian seperti motivasi kerja, stres kerja, lingkungan kerja dan lainnya.

\section{f. Uji Goodness of Fit}

Pengujian selanjutnya adalah uji Goodness of Fit ditinjau dari nilai Chi Square dengan $\mathrm{p}=0,212>0,05$; Cmin/DF $\quad(0,554<2), \quad$ RMSEA $(0,059<0,08)$, TLI $(0,994>0,90)$, CFI $(0.984>0,9)$. Untuk GFI $(0,995>0,9)$ dan AGFI $(0,952>0,9)$ dinyatakan bahwa model memenuhi asumsi Goodness of fit (model fit yang baik).

Hasil Uji Goodness of Fit

\begin{tabular}{cccc}
\hline Goodness of fit & Cut - off Value & Hasil Model & Keterangan \\
\hline $\mathbf{X}^{\mathbf{2}}$-Chi Square & $\begin{array}{c}\text { Diharapkan } \\
\text { nilainya kecil } \\
\text { dengan DF=1 nilai } \\
\text { tabelnya }=3.815\end{array}$ & 1,554 & Baik \\
\hline Probability & $>0,05$ & 0,212 & Baik \\
\hline Cmin/DF & $<2$ & 0,554 & Baik \\
\hline GFI & $>0,90$ & 0,995 & Baik \\
\hline
\end{tabular}


Pengaruh Konflik Peran dan Jenjang Karir terhadap Produktivitas Karyawan dengan Komitmen Organisasional sebagai Variabel Mediasi di RS Leona Kupang

\begin{tabular}{cccc}
\hline Goodness of fit & Cut - off Value & Hasil Model & Keterangan \\
\hline RMSEA & $<0,079$ & 0,059 & Baik \\
\hline AGFI & $>0,90$ & 0,952 & Baik \\
\hline TLI & $>0,90$ & 0.994 & Baik \\
\hline CFI & $>0,90$ & 0.984 & Baik \\
\hline
\end{tabular}

\section{g. Uji Parsial}

Berdasarkan tabel di bawah ini menunjukkan bahwa pengaruh konflik peran terhadap komitmen organisasional memiliki CR sebesar 3,485 sedangkan pengaruh jenjang karir terhadap komitmen organisasional memiliki CR 3,802. Untuk pengaruh komitmen organisasional terhadap produktivitas kerja memiliki CR 5,189, dan untuk pengaruh jenjang karir terhadap produktivitas kerja memiliki CR -3,870 serta pengaruh jenjang karir terhadap produktivitas karyawan memiliki CR 3,873.

Table 5

Regression Weight

\begin{tabular}{lccccc}
\hline \multicolumn{1}{c}{ Variabel } & Standard Estimate & S.E. & C.R. & P & Ket \\
\hline $\begin{array}{l}\text { Konflik peran terhadap } \\
\text { Komitmen } \\
\text { organisasional }\end{array}$ & -0.258 & 0.068 & $\begin{array}{c}- \\
-485\end{array}$ & $\begin{array}{c}0.0 \\
00\end{array}$ & $\begin{array}{c}(\mathrm{H} 2) \\
\text { Diterima }\end{array}$ \\
\hline $\begin{array}{l}\text { Jenjang karir terhadap } \\
\begin{array}{l}\text { Komitmen } \\
\text { organisasional }\end{array}\end{array}$ & 0.281 & 0.086 & 3.802 & $\begin{array}{c}0.0 \\
00\end{array}$ & $\begin{array}{c}\text { (H3) } \\
\text { Diterima }\end{array}$ \\
\hline $\begin{array}{l}\text { Komitmen } \\
\text { organisasional terhadap } \\
\text { Produktivitas karyawan }\end{array}$ & 0.359 & 0.042 & 5.189 & $\begin{array}{c}0.0 \\
00\end{array}$ & $\begin{array}{c}\text { (H4) } \\
\text { Diterima }\end{array}$ \\
\hline $\begin{array}{l}\text { Konflik peran terhadap } \\
\text { Produktivitas karyawan }\end{array}$ & -0.257 & 0.037 & $\begin{array}{c}- \\
\text { J }\end{array}$ & $\begin{array}{c}0.0 \\
00\end{array}$ & $\begin{array}{c}\text { (H5) } \\
\text { Diterima }\end{array}$ \\
\hline $\begin{array}{l}\text { Jenjang karir terhadap } \\
\text { Produktivitas karyawan }\end{array}$ & 0.259 & 0.047 & 3.873 & $\begin{array}{c}0.0 \\
00\end{array}$ & $\begin{array}{c}\text { (H6) } \\
\text { Diterima }\end{array}$ \\
\hline
\end{tabular}

\section{B. Pembahasan}

Pengaruh secara bersama-sama antara konflik peran, jenjang karir, dan komitmen organisasional terhadap produktivitas karyawan

Berdasarkan hasil penelitian, didapatkan hasil Chi-square sebesar 1,544 degrees of freedom sebesar 1 dan probability level 0,212 maka uji simultan diterima. Hasil analisis koefisen determinasi (R2) didapatkan pengaruh konflik peran, jenjang karir dan komitmen organisasional terhadap produktivitas karyawan sebesar 35,7\%, sedangkan sisanya adalah sebesar $64,3 \%$ dipengaruhi oleh faktor lain diluar penelitian seperti motivasi kerja, stres kerja, lingkungan kerja dan lainnya.

Selain itu untuk menguji signifikansi pengaruh mediasi komitmen organisasional pada hubungan konflik peran dan jenjang karir terhadap produktivitas karyawan digunakan uji pengaruh tidak langsung dengan menunjukkan bahwa konflik peran berpengaruh terhadap produktivitas karyawan dengan komitmen organisasional sebagai variabel intervening yang terbukti signifikan. Hal ini ditunjukkan dengan nilai estimasi sebesar -0,093 dengan CR sebesar -3,467 dan p-value sebesar 0,000 (p-value $<0,05$ ). Hasil pengujian pengaruh tidak langsung 
yang menunjukkan bahwa jenjang karir berpengaruh terhadap produktivitas karyawan dengan komitmen organisasional sebagai variabel intervening yang terbukti signifikan. Hal ini ditunjukkan dengan nilai estimasi sebesar 0,101 dengan CR sebesar 3,052 dan p-value sebesar 0,002(p-value $<0,05$ ). Hal ini tampak pada gambar 4.1 yang menunjukkan nilai estimasi uji intervening-nya.

Hasil ini didukung dengan nilai Chi Square sebesar $1.554<$ Chi square Tabel (3.815) dan probabilitas $\mathrm{p}=0,212>0,05$ yang menunjukkan bahwa model keseluruhan telah fit. Dengan demikian secara serentak jenjang karir dan konflik peran berpengaruh terhadap produktivitas karyawan dengan komitmen organisasional sebagai variabel mediasi dapat diterima dan telah memenuhi model yang telah fit atau model yang sesuai.

H1: Terdapat pengaruh signifikan secara bersama-sama antara konflik peran, jenjang karir, dan komitmen organisasional terhadap produktivitas karyawan di Rumah Sakit secara simultan, diterima.

Gambar 2

\section{Uji Hipotesis dan Uji Intervening}

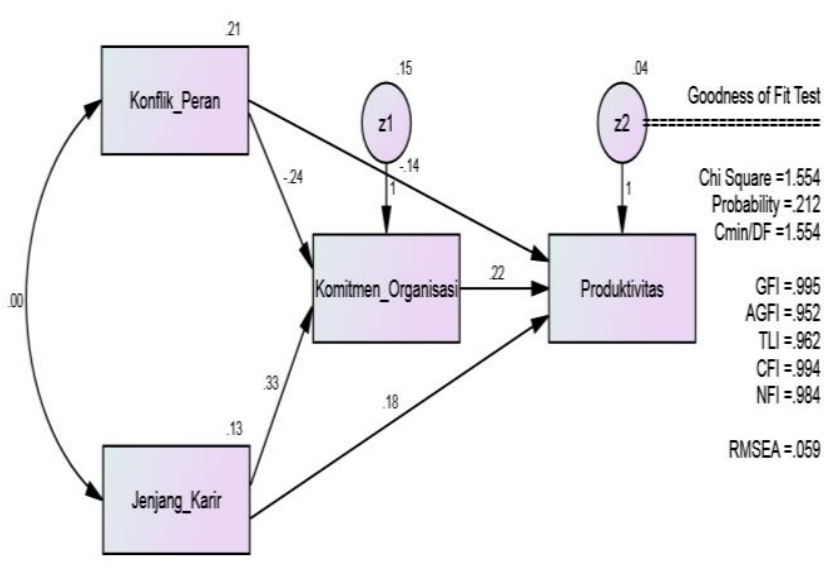

Pengaruh konflik peran terhadap komitmen organisasional

Melalui penghitungan statistik menggunakan Amos V21 diketahui bahwa estimasi pengaruh konflik peran terhadap komitmen organisasional sebesar $-0,258$, nilai CR $-3,485$ dan p-value $0,000<0,05$ maka Ho ditolak dan $\mathrm{H} 2$ diterima, artinya terdapat pengaruh negatif dan signifikan antara konflik peran terhadap komitmen organisasional. Berdasarkan nilai estimasi konflik peran memberikan pengaruh $25,8 \%$ terhadap komitmen organisasional, sisanya $74,2 \%$ dipengaruhi oleh variabel lain, maka dapat disimpulkan bahwa konflik peran berpengaruh negatif dan signifikan terhadap komitmen organisasional.

H2: Terdapat pengaruh signifikan konflik peran terhadap komitmen organisasional karyawan di Rumah Sakit, diterima.

Pengaruh jenjang karir terhadap komitmen organisasional

Berdasarkan hasil pengujian statistik pada nilai estimasi diketahui bahwa pengaruh jenjang karir terhadap komitmen organisasional sebesar 0,281 nilai CR 2,802 dan p-value $0,000<0,05$, maka $\mathrm{H} 0$ ditolak dan $\mathrm{H} 3$ diterima. Artinya jenjang karir berpengaruh positif dan 
Pengaruh Konflik Peran dan Jenjang Karir terhadap Produktivitas Karyawan dengan Komitmen Organisasional sebagai Variabel Mediasi di RS Leona Kupang

signifikan terhadap komitmen organisasional. Berdasarkan nilai estimasi jenjang karir memberikan pengaruh $28,1 \%$ terhadap komitmen organisasional, sisanya $71,9 \%$ dipengaruhi oleh variabel lain, maka dapat disimpulkan bahwa jenjang karir berpengaruh positif dan signifikan terhadap komitmen organisasional.

H3: Terdapat pengaruh signifikan jenjang karir terhadap komitmen organisasional karyawan di RS, diterima.

Pengaruh komitmen organisasional terhadap produktivitas karyawan

Berdasarkan hasil pengujian statistik pada nilai estimasi diketahui bahwa pengaruh komitmen organisasional terhadap produktivitas karyawan sebesar 0,359, nilai CR 5,189 dan p-value 0,000, artinya terdapat pengaruh positif dan signifikan antara komitmen organisasional terhadap produktivitas karyawan maka $\mathrm{H} 0$ ditolak dan $\mathrm{H} 4$ diterima. Dari nilai estimasi pengaruh komitmen organisasional terhadap produktivitas karyawan sebesar $35,9 \%$ dan sisanya $64,1 \%$ dipengaruhi variabel lainnya. Berdasarkan hasil tersebut maka dapat disimpulkan bahwa semakin tinggi komitmen organisasional menjadikan produktivitas karyawan semakin tinggi.

H4: Terdapat pengaruh signifikan hubungan komitmen organisasional terhadap produktivitas karyawan di Rumah Sakit, diterima.

Pengaruh konflik peran terhadap produktivitas karyawan

Berdasarkan hasil penelitian, diketahui bahwa pada nilai estimasi pengaruh konflik peran terhadap produktivitas karyawan sebesar $-0,257$ nilai CR sebesar 3,870 dan p-value $0,001<$ 0,05 , nilai ini menunjukkan hasil yang memenuhi syarat yaitu $<0,05$ untuk $\mathrm{P}$, sehingga dapat disimpulkan Ho ditolak dan H5 diterima. Dari nilai estimasi pengaruh konflik peran terhadap produktivitas karyawan sebesar 25,7\%, sisanya $74,3 \%$ dipengaruhi variabel lainnya. Berdasarkan hasil tersebut maka dapat disimpulkan bahwa konflik peran berpengaruh negatif dan signifikan terhadap produktivitas karyawan. Semakin tinggi konflik peran yang terjadi akan menurunkan produktivitas kerja karyawan.

H5: Terdapat pengaruh signifikan konflik peran terhadap produktvitas karyawan di RS, diterima.

Pengaruh jenjang karir terhadap produktivitas karyawan

Melalui perhitungan pengujian statistik menggunakan Amos-path analysis V21 diketahui bahwa pada nilai estimasi pengaruh jenjang karir terhadap produktivitas karyawan sebesar 0,259 nilai CR 3,873 dan p-value $0,000<0,05$, nilai ini menunjukan hasil yang memenuhi syarat kurang dari 0,05 untuk $\mathrm{P}$, sehingga dapat simpulkan H0 ditolak dan H6 diterima. Dari nilai estimasi pengaruh konflik peran terhadap produktivitas karyawan sebesar $25,9 \%$, sisanya $74,1 \%$ dipengaruhi variabel lainnya. Berdasarkan hasil tersebut maka dapat disimpulkan bahwa jenjang karir berpengaruh positif dan signifikan terhadap produktivitas karyawan. Semakin baik jenjang karir yang dirasakan karyawan maka produktivitas kerjanya akan semakin meningkat.

H6: Terdapat pengaruh signifikan jenjang karir terhadap produktivitas karyawan di Rumah Sakit, diterima.

Pada penelitian ini menguji beberapa hipotesa baik simultan maupun parsial.

Pengaruh signifikan secara bersama-sama antara konflik peran, jenjang karir, dan komitmen organisasional terhadap produktivitas karyawan di Rumah Sakit secara simultan

Berdasarkan uji koefsien determinasi, variabel konflik peran, 
jenjang karir dan komitmen organisasional mempengaruhi produktivitas karyawan sebesar $35,7 \%$, sedangkan sisanya $64,3 \%$ dipengaruhi oleh variabel lain diluar penelitian ini seperti motivasi kerja, stres kerja, lingkungan kerja dan lainnya.

Berdasarkan Analisa distribusi responden dengan menggunakan three box methode, distribusi responden nilai indeks rata-rata 53,51 terletak pada kategori cukup/sedang. Hal menunjukkan bahwa produktivitas karyawan selama ini cukup tinggi dengan mayoritas jawaban yaitu $57 \%$ menyatakan produktivitas karyawannya netral. Hasil penelitian ini sejalan dengan penelitian (Fatah-Black, 2014) di Surakarta. Pada penelitian ini didapatkan hasil konflik peran, jenjang karir dan komitmen organisasional memiliki pengaruh terhadap produktivitas karyawan. Dimana di RS Leona ini produktivitas karyawan ini dipengaruhi oleh banyak faktor didalamnya. dan untuk meningkatkan produktivitas karyawan di RS Leona ini mungkin diperlukan menataan manajemen lebih lanjut.

Pengaruh konflik peran terhadap komitmen organisasional

Berdasarkan uji koefisien determinasi, komitmen organisasional sebesar $25,8 \%$, sedangkan sisanya $74,2 \%$ dipengaruhi oleh variabel lain diluar penelitian ini.

Adanya pengaruh negatif dan signifikan konflik peran terhadap komitmen organisasional menunjukkan bahwa semakin tinggi konflik peran yang dirasakan oleh karyawan rumah sakit Leona Kupang, maka akan menimbulkan menurunnya komitmen karyawan. pengaruh negatif dari konflik peran terhadap kepuasan kerja maupun komitmen organisasional telah diperhatikan banyak literatur. Hal ini menjelaskan bahwa konflik peran memiliki pengaruh langsung dan negatif terhadap komitmen organisasional.

Berdasarkan analisis distribusi responden dengan three box methode, rata-rata distribusi responden nilai indeks rata-rata 58,66 terletak pada kategori sedang. Nilai indeks tertinggi terdapat pada indikator Strain Based Conflict yaitu "Saya bekerja dengan dua atau lebih kelompok yang beroperasi secara berbeda". Nilai indeks terendah terdapat pada indikator Time Based Conflict yaitu "Saya harus melakukan sesuatu (kegiatan) yang harus dilakukan secara berbeda". Konflik peran yang terjadi pada karyawan di Rumah Sakit Leona Kupang masih dalam kategori sedang dengan harapan karyawan terutama pada kegiatan yang berbeda dimana $52 \%$ karyawan menyatakan ragu-ragu jika harus melakukan kegiatan yang berbeda. Berdasarkan temuan tersebut maka pihak manajemen rumah sakit perlu memberikan rotasi pekerjaan yang terprogram, sehingga setiap karyawan dapat melakukan pekerjaan yang berbeda-beda dalam kurun waktu tertentu, sehingga akan menurunkan tingkat kebosanan, dengan memberikan job atau pekerjaan yang berbeda.

Selain itu pada indikator Behaviour Based Conflict terutama pada item Saya bekerja dengan pedoman dan kebijakan yang tidak sesuai (cocok) juga masih dinilai paling rendah kedua oleh karyawan. Untuk itu kebijakan-kebijakan rumah sakit perlu memperhatikan aspirasi bawahan, sehingga tugas-tugas yang diselesaikan ada kesesuaikan antara harapan karyawan dan kebijakan rumah sakit. Hal ini didukung dengan indikator Saya harus mengesampingkan aturan atau kebijakan agar dapat menyelesaikan tugas yang mayoritas 54\% menyatakan raguragu. 
Pengaruh Konflik Peran dan Jenjang Karir terhadap Produktivitas Karyawan dengan Komitmen Organisasional sebagai Variabel Mediasi di RS Leona Kupang

Ini sejalan dengan penelitian (Wulandari \& Prianthara, 2018), (Henry et al., 2013), (Tseng et al., 2012) yang menemukan bahwa konflik peran berpengaruh negatif terhadap komitmen organisasional.

Pada RS Leona Kupang ditemukan konflik peran mempengaruhi komitmen organisasi mungkin perlu adanya penataan jadwal kerja karyawan.

Pengaruh jenjang karir terhadap komitmen organisasional

Berdasarkan uji koefisien determinasi, variabel jenjang karir memberikan pengaruh $28,1 \%$ terhadap komitmen organisasional, sisanya $71,9 \%$ dipengaruhi oleh variabel lain diluar penelitian.

Adanya pengaruh positif menunjukkan bahwa jenjang karir yang dirasakan karyawan semakin baik maka komitmen organisasionalnya akan semakin meningkat.

Dan berdasarkan analisis deskriptif dengan three box methode, nilai indeks rata-rata 53,46 terletak pada kategori sedang. Nilai indeks tertinggi 70 terdapat pada indikator kebijakan organisasi yaitu "Posisi bekerja sudah sesuai dengan pendidikan". Nilai indeks terendah terdapat pada indikator pelatihan yaitu "Karyawan diberikan kesempatan untuk seleksi karyawan internal dalam posisi yang dibutuhkan", dengan nilai indeks 51,65. Karyawan merasakan kesempatan mendapatkan seleksi karyawan dalam posisi tertentu sebanyak $47 \%$ karyawan menilai ragu-ragu dan tidak setuju bahwa pelaksanaan seleksi tersebut cukup baik.

Hasil ini memberikan implikasi bahwa keadilan dalam seleksi internal karyawan untuk mendapatkan posisi jabatan yang lebih tinggi sangat penting dalam menentukan komitmennya untuk setia pada rumah sakit. Karyawan yang merasa adanya ketidakadilan, akan mudah merasakan kekecewaan, karena peluangnya mendapatkan karir yang lebih baik tertutup, sehingga dapat menimbulkan niat untuk meninggalkan organisasi. Untuk itu pihak rumah sakit hendaknya dalam perekrutan selesksi internal lebih transparan dan dapat dipertanggung jawabkan sehingga proses seleksi ini mampu memberikan rasa keadilan.

Hasil penelitian ini mendukung penelitian sebelumnya yang dilakukan (Naomi Helena Paulus, 2019) (Pitri, 2017) dan penelitian (Susi, 2016) yang menemukan bahwa pengembangan karir berpengaruh positif dan signifikan terhadap komitmen organisasional. RS Leona tidak memiliki jenjang karir yang jelas, sehingga komitmen organisasinya menjadi kurang, perlu adanya pelatihan kerja yang efektif untuk menopang jenjang karir dalam RS ini.

Pengaruh komitmen organisasional terhadap produktivitas karyawan

Komitmen organisasional berpengaruh positif dan signifikan terhadap produktivitas karyawan hal ini dilihat dari nilai estimasi pengaruh komitmen organisasional terhadap produktivitas karyawan sebesar 35,9\% dan sisanya $64,1 \%$ dipengaruhi variabel lainnya. Berdasarkan hasil tersebut maka dapat disimpulkan bahwa semakin tinggi komitmen organisasional menjadikan produktivitas karyawan semakin tinggi.

Dan analisis deskriptif dengan three box methode, nilai indeks rata-rata 54,14 terletak pada kategori sedang. Nilai indeks tertinggi terdapat pada indikator komitmen normatif yaitu "Saya merasa perusahaan ini telah banyak berjasa bagi hidup saya" dengan nilai indeks 55,44. Nilai indeks terendah terdapat pada indikator komitmen normatif dengan nilai 52,41 yaitu "Saya merasa belum memberikan banyak kontribusi bagi perusahaan ini.", terdapat 
49\% karyawan ragu-ragu dengan memberikan banyak kontribusi bagi perusahaan ini

Hasil penelitian mendukung penelitian yang dilakukan oleh (Hernawati et al., 2017) menjelaskan bahwa komitmen organisasional berpengaruh positif dan signifikan terhadap produktivitas karyawan PT Home Center Indonesia Medan secara parsial dan serentak. Begitu pula dengan penelitian yang dilakukan oleh Natalia P. M., dkk pada tahun 2019 menjelaskan komitmen organisasional berpengaruh positif dan signifikan terhadap produktivitas kerja. Sehingga komitmen organisasional pun penting dalam menghasilkan outcome yang baik dalam produktivitas karyawan rumah sakit khususnya RS Leona ini.

Pengaruh konflik peran terhadap produktivitas karyawan

Berdasarkan uji koefisien determinasi, variabel konflik peran berpengaruh negatif dan signifikan terhadap produktivitas karyawan. Dari nilai estimasi pengaruh konflik peran terhadap produktivitas karyawan sebesar $25,7 \%$, sisanya $74,3 \%$ dipengaruhi variabel lainnya. Berdasarkan hasil tersebut maka dapat disimpulkan bahwa konflik peran berpengaruh terhadap produktivitas karyawan. Adanya pengaruh negatif menunjukkan bahwa besarnya konflik yang terjadi pada karyawan akan menurunkan produktivitas kerja. Penelitian tersebut menghasilkan temuan bahwa konflik peran berpengaruh negatif terhadap produktivitas karyawan, sehingga jika terdapat konflik peran maka produktivitas karyawan akan menurun. Demikian juga sebaliknya jika tidak terjadi konflik peran maka produktivitas karyawan akan lebih baik.

Berdasarkan Analisa deskriptif dengan menggunakan three box methode pada variabel konflik peran, indeks tertinggi terdapat pada indikator Strain Based Conflict yaitu "Saya bekerja dengan dua atau lebih kelompok yang beroperasi secara berbeda" dengan skor 60.13. Nilai indeks terendah terdapat pada indikator Time Based Conflict yaitu "Saya harus melakukan sesuatu (kegiatan) yang harus dilakukan secara berbeda" yaitu 55.06. Konflik peran yang terjadi pada karyawan di Rumah Sakit Leona Kupang masih dalam kategori sedang dengan harapan karyawan terutama pada kegiatan yang berbeda dimana $52 \%$ karyawan menyatakan ragu-ragu jika harus melakukan kegiatan yang berbeda. Hasil ini menunjukkan bahwa pihak rumah sakit perlu memperhatikan konflik yang terjadi pada karyawannya, tertutama konflik yang berbasis waktu.

Hasil penelitian mendukung hasil penelitian yang dilakukan oleh Nurul P., dkk (2013), Neneng N.A (2019), M. Rovithis, M., dkk (2016) yang secara konsisten menemukan bahwa konflik peran berpengaruh terhadap penurunan produktivitas kerja.

Pengaruh jenjang karir terhadap produktivitas karyawan

Melalui perhitungan pengujian statistik diketahui bahwa jenjang karir berpengaruh positif dan signifikan terhadap produktivitas karyawan. Dari nilai estimasi pengaruh konflik peran terhadap produktivitas karyawan sebesar $25,8 \%$, sisanya $74,2 \%$ dipengaruhi variabel lainnya. Maka dapat disimpulkan bahwa jenjang karir berpengaruh positif dan signifikan terhadap produktivitas karyawan.

Berdasarkan Analisa deskriptif dengan three box methode, indeks tertinggi 70 terdapat pada indikator kebijakan organisasi yaitu "Posisi bekerja sudah sesuai dengan pendidikan". Nilai indeks terendah terdapat pada indikator pelatihan yaitu "Karyawan diberikan 
Pengaruh Konflik Peran dan Jenjang Karir terhadap Produktivitas Karyawan dengan Komitmen Organisasional sebagai Variabel Mediasi di RS Leona Kupang

kesempatan untuk seleksi karyawan internal dalam posisi yang dibutuhkan", dengan nilai indeks 51,65. Karyawan merasakan kesempatan mendapatkan seleksi karyawan dalam posisi tertentu sebanyak $47 \%$ karyawan menilai raguragu dan tidak setuju bahwa pelaksanaan seleksi tersebut sudah baik.

Indikator pelatihan merupakan indikator yang dinilai paling rendah, sehingga menunjukkan bahwa usaha dari rumah sakit untuk memberikan bimbingan, pelatihan dan pengembangan bagi karyawan rumah sakit ini masih rendah. Sebagaimana telah diketahui bersama bahwa Rumah Sakit bersama-sama karyawan itu sendiri memiliki tanggung jawab dalam mengembangkan kompetensi karyawan. Namun demikian, rumah sakit sebagai suatu organisasi memiliki kemampuan dan kekuatan yang lebih besar untuk menciptakan suatu sistem/ mekanisme pengembangan kompetensi karyawan. Kompentensi penting dibutuhkan karyawan untuk menempati posisi tertentu. Rendahnya pelatihan karyawan tentunya akan menghambat kompetensi karyawan rumah sakit, sehingga jeneng karir akan terhambat juga.

Memang tidak dipungkiri bahwa training/ pelatihan bukanlah one stop solution. Artinya, tidak semua masalah kurangnya kinerja karyawan dapat diatasi dengan membuat atau mengirim karyawan mengikuti pelatihan tertentu. Begitu banyak pelatihan yang diikuti staf, namun output yang diharapkan belum tentu tercapai. Agar pelatihan dapat efektif dan efisien, rumah sakit perlu melakukakan beberapa hal penting. Hal penting yang pertama adalah melakukan analisis kebutuhan pelatihan, kemudian menentukan jenis/ metode pelatihan, serta melakukan follow up termasuk evaluasi atas pelatihan yang diselenggarakan/ diikuti
Hal ini menunjukkan bahwa dengan jenjang karir yang baik dalam bekerja akan semakin baik produktivitas karyawan karyawan sedangkan jenjang karir yang lebih tidak baik akan berakibat pada rendahnya produktivitas karyawan karyawan pula. Lebih jauh menyatakan bahwa jenjang karir dapat dikatakan samasama tepat ketika seorang karyawan dapat melakukan aktivitas secara optimal, sehat, aman, dan nyaman, sedangkan jenjang karir yang kurang baik membutuhkan tenaga kerja dan lebih banyak waktu dan tidak mendukung mendapatkan desain sistem kerja yang efisien. Jenjang karir dapat secara langsung mempengaruhi karyawan dalam meningkatkan produktivitas karyawan karyawan. Sebaliknya jenjang karir yang tidak memadai akan dapat menurunkan produktivitas karyawan karyawan

Hasil penelitian ini mendukung penelitian penelitian yang dilakukan oleh (Juwita, 2020), (Kosegeran et al., 2019), dan (Raditya \& Subagyo, 2017) yang menemukan secara konsisten bahwa Pengembangan karir berpengaruh secara langsung dan signifikan terhadap Produktivitas.

\section{Kesimpulan}

Konflik peran berpengaruh negatif dan signifikan terhadap komitmen organisasional dan produktivitas kerja sedangkan jenjang karir berpengaruh positif dan signifikan terhadap komitmen organisasional dan produktivitas karyawan. Artinya konflik peran yang rendah dan jenjang karir yang baik akan dapat menumbuhkan komitmen karyawan untuk selalu setia terhadap rumah sakit ini dan meningkatkan produktivitas karyawan.

Konflik peran dan jenjang karir dapat meningkatkan produktivitas karyawan secara langsung tetapi juga dapat berpengaruh secara tidak langsung melalui komitmen 
organisasional. Temuan lainnya yaitu komitmen organisasional memiliki nilai pengaruh paling besar untuk meningkatkan produktivitas karyawan dibandingkan dengan konflik peran dan jenjang karir, hal ini sesuai dengan teori yang dikemukakan oleh Mathis and Jackson (2001), yang menyatakan bahwa karyawan dikatakan memiliki komitmen organisasional yang baik jika karyawan tersebut mempunyai keinginan untuk tetap ada didalam organisasi tersebut yang pada akhirnya tergambar dalam statistik ketidakhardiran dan masuk keluar tenaga kerjanya.

Pada RS Leona Kupang mungkin perlu diciptakannya sistem jenjang karir agar dapat menciptakan produktivitas kerja yang baik dan perlu adanya uraian tugas yang jelas sehingga tidak terjadi konflik peran pada karyawan rumah sakit. Serta dibutuhkan adanya sistem penilaian kinerja agar karyawan berusaha untuk meningkatkan produktivitas dan diharapkan komitmen organisasionalnya akan meningkat juga. Hal ini harus diperhatikan oleh manajemen RS Leona agar produktivitas karyawannya optimal

\section{BIBLIOGRAFI}

Carnicer, J. M., \& Gasca, M. (2004). Classification of Bivariate Configurations With Simple Lagrange Interpolation Formulae. Advances In Computational Mathematics, 20(1), 516. Google Scholar

Fatah-Black, K. (2014). Paramaribo As Dutch And Atlantic Nodal Point, 1640-1795. In Dutch Atlantic Connections, 16801800 (Pp. 52-71). Brill. Google Scholar

Glueck, C. J., Freiberg, R., Tracy, T., Stroop, D., \& Wang, P. (1997). Thrombophilia And Hypofibrinolysis: Pathophysiologies Of Osteonecrosis. Clinical Orthopaedics And Related Research, 334, 43-56. Google Scholar
Henry, E., Yadeta, K. A., \& Coaker, G. (2013). Recognition Of Bacterial Plant Pathogens: Local, Systemic And Transgenerational Immunity. New Phytologist, 199(4), 908-915. Google Scholar

Hernawati, L., Rahayu, E., \& Soejowinoto, P. (2017). Enhancing Indonesian High School Students' Understanding On Anger Management. Journal of Economic \& Management Perspectives, 11(1), 1632-1638. Google Scholar

Indarjanti, P., \& Bodroastuti, T. (2012). Pengaruh Kemampuan, Usaha Dan Dukungan Organisasi Terhadap Kinerja. Jurnal Kajian Akuntansi Dan Bisnis, 1(1), 102597. Google Scholar

Juwita, J. (2020). Tantangan Widyaiswara Badiklat Kemhan Di Era Revolusi Industri 4.0 Dalam Peningkatan Mutu Pendidikan Dan Pelatihan. Jurnal Pendidikan Indonesia, 1(2), 77-93. Google Scholar

Kosegeran, M. G., Pangemanan, D. H., \& Hamel, R. S. (2019). Hubungan Tipe Kepribadian Dengan Kinerja Perawat Di Ruangan Rawat Inap Rsu Gmim Bethesda Tomohon. Jurnal Keperawatan, 7(1). Google Scholar

Naomi Helena Paulus, N. (2019). Identifikasi Virus Influenza Dan Rhinovirus Berdasarkan Gambaran Klinis Dan Pemeriksaan Penunjangn Pada Anak Usia 2-59 Bulan Dengan Pneumonia Di Rsud Dr. Soetomo. Universitas Airlangga. Google Scholar

Pitri, N. (2017). Pengaruh Stres Kerja, Kompensasi Dan Pengembangan Karir Terhadap Komitmen Organisasional Perawat Di Rumah Sakit Jiwa Mutiara Sukma Mataram Provinsi Ntb. Jmm Unram-Master Of Management Journal, 6(4). Google Scholar

Raditya, C., \& Subagyo, A. (2017). Hubungan Faktor Manusia Dan Lingkungan Fisik Rumah Dengan 
Pengaruh Konflik Peran dan Jenjang Karir terhadap Produktivitas Karyawan dengan Komitmen Organisasional sebagai Variabel Mediasi di RS Leona Kupang

Kejadian Penyakit Tuberkulosis Paru Di Wilayah Kerja Puskesmas Cilongok I Tahun 2016. Buletin Keslingmas, 36(3), 269-278. Google Scholar

Robbins, M., Judge, A., \& Maclachlan, I. (2009). Sirna And Innate Immunity. Oligonucleotides, 19(2), 89-102. Google Scholar

Susi, S. (2016). The Association Between Severity Of Malocclussion With Caries Among Adolescents Students Of Smkn 3 Pariaman. Andalas Dental Journal, 4(1), 28-38. Google Scholar
Tseng, H. F., Chi, M., Smith, N., Marcy, S. M., Sy, L. S., \& Jacobsen, S. J. (2012). Herpes Zoster Vaccine And The Incidence Of Recurrent Herpes Zoster In An Immunocompetent Elderly Population. The Journal Of Infectious Diseases, 206(2), 190-196. Google Scholar

Wulandari, R., \& Prianthara, I. B. T. (2018). Role Stress, Kompensasi Finansial, Motivasi Kerja Dan Kepuasan Kerja. Jurnal Manajemen Bisnis, 15(3), 154168. Google Scholar

\section{Copyright holder:}

Mitzi, Muhammad Fachruddin Arrozi, Rina Anindita (2022)

First publication right:

Jurnal Health Sains

This article is licensed under: 